\title{
REAL ESTATE AND TRANSACTIONS INVOLVING FOREIGN INVESTORS CARRYING OUT REAL ESTATE AND RELATED BUSINESSES IN THAILAND
}

\author{
Vira Kammee
}

\begin{abstract}
Thailand is one of the fast growing economies in the South East Asian region. Investment is a much needed instrument or vehicle in driving the economy forward and building the country into the 21st Century. Being a country that is very popular amongst foreigners, there is much interest from foreigners to invest into the country, which is a really good sign as it only shows that the country's economy is doing well. However, how much of that is a welcome investment under the current rules and regulations. As much as foreign investment is a real welcome - what are their limitations and to what extent can they be brought in? Are the restriction imposed under the existing regulations, very firm or are they flexible and if there are ways to go around it. To what extent can funds from outside the country be used in the development and enhancing the various developments which are essential in building the economy towards a leading economy in this region.
\end{abstract}

INTRODUCTION

I. STATUTORY ACQUISITION OF RIGHT TO THE LAND FOR THE FOREIGN INVESTORS

A. Land Code.

B. The Civil and Commercial Code of Thailand, B.E. 2535 (A.D. 1992)

C. Hire of Immovable Property for Commerce and Industry Act, B.E. 2542 (A.D. 1999) 694

D. $\quad$ The Foreign Business Act, B.E. 2542 (A.D. 1999) ................... 695

E. Investment Promotion Act, B.E. 2520 (A.D. 1977)...................695

F. Industrial Estate Authority of Thailand Act, B.E. 2522 (A.D. 1979)

G. Petroleum Act, B.E. 2514 (A.D. 1971)

II. Development or Investment in the Real Estate Business with Respect to Land. 695

A. Town Planning Act, B.E. 2518 (A.D. 1975)................................696

B. $\quad$ Thailand Building Control Act, B.E. 2522 (A.D. 1979) ........... 696

$C$. The Enhancement and Conservation of the National Environmental Quality Act, B.E. 2535 (A.D. 1992). 697

D. Other Laws 697

*Partner, Siam City Law Offices Limited. This is based on Mr. Kammee's 35 years of experience in the development of real estate business in Thailand. 
III. NEW DRAFT LAW RELATING TO LAND AND BUILDING TAXES EXPECTED TO BE IN ForCE BY B.E. 2560 (A.D. 2017) (SUPERSEDING THE CURRENT Thai Property TAX LAW, NAMELY THE LAW ON BUILDING AND LAND TAXES, AND LOCAL ADMINISTRATION TAXES). 700

IV. SECURITISATION OF THE COMPANY'S ASSETS, WHICH ARE THE REAL ESTATE OR Right IN THE REAL Estate, TO BE SECURITIES UNDER THE CATEGORY OF "INSTRUMENT FOR Distribution to THE GENERAL PUblic" THROUGH THE ESTABLISHMENT OF THE REIT 701 CONCLUSION 702

\section{INTRODUCTION}

This article deal with the real estate development business and investment in property by foreigners in Thailand. The paper focus particularly on Thailand's position: As to how Thailand welcomes foreign investments and commerce, and what the legal requirements are in order to set up a base in Thailand in terms of tenure or the purchase, or ownership of land and property. Foreign investors may take into consideration the four following main issues relating to the intended business operation, as well as the legal implications of the applicable laws mentioned below:

1. Statutory acquisition of right to the land for the foreign investors.

2. Development or investment in the real estate business with respect to land.

3. New draft law relating to the land and building taxes, which is expected to be in force in B.E. 2560 (A.D. 2017) (superseding the current Thai property tax law, namely the law on building and land taxes, and local administration taxes).

4. Securitisation of the company's assets, which are real estate or right in the real estate, to be securities under the category of instrument for distribution to the general public through the establishment of the Real Estate Investment Trust (REIT).

\section{STATUTORY ACQUiSITION OF Right TO THE LAND FOR THE FOREIGN INVESTORS}

Acquisition of right to the land for the foreign investors in order to develop or operate the real estate business, or the business requiring use of the land as a location for running the business in Thailand, is divisible into two categories, namely the ownership right, right to possession and utilisation in the land from the land lease.

The right to use the land by the foreign investors for development or 
operation of a business associated with real estate may be secured by virtue of the following legal rights.

\section{A. Land Code}

There is no provision in the Land Code bestowing a right on foreigners, either natural or juristic persons, to own or hold a title in the land in Thailand. The foreign natural and juristic persons are entitled to joint investment with Thai partners in order to establish the juristic person. The foreign investors can hold shares not more than $49 \%$ of the number of total shares, and the remaining $51 \%$ shares shall be held by a natural person carrying Thai Nationality or a Thai juristic person.

In the case where the foreign investors desire to personally invest without making a joint investment with the Thai national or juristic person, the foreign investors may seek permission from the competent official to own the land by relying on the legal rights under Clauses 1.5 or 1.6 or 1.7.

\section{B. The Civil and Commercial Code of Thailand, B.E. 2535 (A.D. 1992)}

Likewise, the Civil and Commercial Code of Thailand (CCC) accords rights to lease the land, of not more than 30 years, to Thai nationals and foreigners under a requirement to register the land leasehold with the competent official under the law. Upon registration of the right and juristic act on the lease or sale of land with the competent official, it is enforceable for a whole term of 30 years. Even if the land owner (the lessor) dies or sells the land to a third party, the third party remains bound under the leasehold of the original lessor until completion of the 30-year lease term, as registered with the legally competent official. To be valid and raised against a third party, the sale of land which is the immovable property shall be made in writing and registered with the competent official. The sale that is not in writing and registered with the competent official shall be void.

C. Hire of Immovable Property for Commerce and Industry Act, B.E. 2542 (A.D. 1999)

Foreign investors in large-scale investments with a long investment period can lease the land for a period of 50 years under the said Act. At present, the Cabinet is considering to amend the lease term from 30 years to not more than 99 years. 
D. The Foreign Business Act, B.E. 2542 (A.D. 1999)

This is a law prescribing the category of businesses reserved for Thai nationals and banning foreigners from carrying certain businesses, and those concerning national security, unless approval is granted by the Minister of Commerce or the Director-General of the Business Development Department.

\section{E. Investment Promotion Act, B.E. 2520 (A.D. 1977)}

The Board of Investment has the authority to consider and grant investment promotion to the company in which foreigners hold shares. The company can apply for permission to be the land owner; For using the land in the business operation for which the investment promotion is granted, with a condition to dispose of the land when the company no longer the land for its business operation.

\section{F. Industrial Estate Authority of Thailand Act, B.E. 2522 (A.D. 1979)}

The Governor of the Industrial Estate Authority of Thailand (IEAT) has the authority to allow the foreign investors - which are foreign juristic persons or Thai juristic persons with foreign investors holding shares greater than $49 \%$ to become owners of land in an industrial estate for the business operation; in accordance with a number of factors set by the IEAT.

\section{G. Petroleum Act, B.E. 2514 (A.D. 1971)}

The Minister of Energy, with approval granted by the Cabinet, is empowered to grant concession to petroleum exploration companies or producers of petroleum. The concessionaire shall be a proprietor of the land area on which the concession is granted.

\section{DEVELOPMENT OR INVESTMENT IN THE REAL ESTATE BUSINESS WITH RESPECT TO LAND}

For development or investment in the real estate business with respect to land, as well as the utilisation of such land for engaging in a business in Thailand, there are the following key laws: 


\section{A. Town Planning Act, B.E. 2518 (A.D. 1975)}

The Town Planning Law of Thailand is a type of law which restricts a right to use a property by an owner or possessor, under which the land utilisation in each of the areas shall be prescribed differently in order to suit the environment, geography, social and economic conditions in each of the localities; with the aim to impose guidance in developing the overall economic and social conditions of each locality to be in line with the overall economic and social policy.

The land utilisation shall be principally classified into: land for dwellings; land for commerce; land for educational institutions; land for religious premises; land for official places; land for countryside and agriculture; land for plants and warehouses; and land for environmental conservation and coastal areas. In each locality, the land use may be subject to sub-categorisation in order to slightly differ from the classification of the principal land utilisation. For instance, the land for commerce, designated as a red area, zone 1-1, can be used for construction of department store buildings, with the area of each building exceeding $30,000 \mathrm{~m}^{2}$; and the designated area of zone 1-2 can be used for construction of department store buildings, with the area of each building not exceeding $10,000 \mathrm{~m}^{2}$; or the land area of a plant and/or warehouse in one Province may be exploited for a business of steel smelting; whereas another area may not be allowed for engaging in such business.

\section{B. Thailand Building Control Act, B.E. 2522 (A.D. 1979)}

For the Building Control Law, it is a law defining a statutory minimum standard for authorising construction, with the intent of protecting the safety of the building's users and those in the surrounding areas whom are susceptible to an impact from construction of the building; thereby requiring that construction of the building, modification of the building or demolition of the building be granted prior permission by the relevant state agency.

Mainly, the minimum standard shall determine the characteristics; structures; empty spaces; spatial distances of each side of the building; lighting the number of toilets; the number of parking spaces; the height to which the buildings can be constructed; width of the walkways; heights of each of the building's floors; fire escapes; areas which are permeable to water (tree and plant growing areas); the number of toilets; building force calculations with regard to materials used and for wind and seismic activity; fire extinguishing system; electricity and water system; and in some areas, it may set out the category of constructible buildings. For instance, for the 
construction of a building within a distance of $100 \mathrm{~m}$ surrounding religious premises; or the construction of a building with a height of over $10 \mathrm{~m}$ is prohibited in the area vulnerable to earthquakes or the land area with a likelihood of subsidence. There shall be a prescribed standard in designing the building and calculating the force pursuant to the items in support of the construction plan of the building; in order to have the main characteristics of the building and structures which are safe and can endure any disaster, natural or otherwise, that may occur.

\section{The Enhancement and Conservation of the National Environmental Quality Act, B.E. 2535 (A.D. 1992)}

Environmental law is a law that sets a standard as to the threshold level of pollution, whether it is from sewage, polluted air or noise pollution; that all kinds of business operations can adhere to. However, for engaging in a certain kind of business with a high risk of causing environmental pollution (e.g. an office building with the internal area of the building exceeding $10,000 \mathrm{~m}^{2}$ or more; a hotel with more than 80 rooms; construction of roads through a forest area; filling of a river basin; filling of a waterway that may result in the diversion of the current water course; mining; petroleum plant; steel industry; and the production of cement, paper pulp, sugar, liquor and alcohol-will require the preparation of a report on Environmental Impact Assessment (EIA). Moreover, for the business which could have a serious impact on the environmental quality, natural resources and health to communities, a report on Environment and Health Impact Assessment (EHIA) shall be prepared as well, such as for the petrochemical industry; ore smelting; metal melting; lead melting; coal fired power plant; biomass power plant, etc.

\section{Other Laws}

In addition to the main laws stated above, there are other laws that must be considered, which relate to the nature of the business that will be developed and invested in by the real estate business in a particular case, as follows.

1. Engaging in the Plant Business (Factory Act B.E. 2535 (A.D. 1992))

For the plant (a building capable of manufacturing goods of all sizes in large quantities to be sold by a business. Plants can be considered either a long term asset if owned by the company, or both a long term liability if 
leased or rented) business, it shall receive prior permission for engaging in the plant business from the government in the case of having machinery of more than 50 horsepower in the plants (the horsepower is not that identified in the machine's specification; rather, it is a reverse calculation means of the horsepower which shall be applied, i.e. the calculation from the electrical energy consumed or thermal energy produced under a rule prescribed by the state). Investment by engaging in the plant business of foreign investors falls within the type of plant requiring permission sought for engaging in the plant business. Furthermore, also considered are the particular characters of each type of plants concerning hygiene, the environment, creation of pollution and others; for which the minimum standard under the plant law has been set.

2. Engaging in the Hotel Business (The Hotel Act, B.E. 2547 (A.D. 2004))

For the hotel business, if engaging in any business in a manner similar to the hotel business, i.e. renting a room with a rental period of less than one month, shall receive permission for engaging in the hotel business from the competent official of the state.

3. Construction of Condominium (The Condominium Act, B.E. 2522 (A.D. 1979))

Apart from a requirement to proceed with construction under the building control law, pre-sale and post-sale administration of the condominium shall comply with the minimum standard set by the underlying principle, and reason of the condominium law. The law on condominiums has the intent to protect a right and exercise of right belonging to the co-owners under a cohabitation agreement, who have bought the condominium units; and the Condominium Juristic Person is an administrator maintaining the central area in the condominium. The condominium consists of two types of property, i.e. communal property and private property. Usage of the personal property shall not cause damage to the central property, nor upset the co-owners in other units living under the cohabitation agreement in the same condominium. "Cohabitation" shall be in accordance with a regulation of the Condominium Juristic Person and the law on condominiums, including the consumer protection law.

4. Land Appropriation by Investors for Residential, Commercial or Industrial Purposes (Land Development Act, B.E. 2543 (A.D. 2000)) 
Land appropriation by investors with respect to development of the real estate business, as well as land appropriation by investors for residential, commercial or industrial purposes, has a rule, condition and stipulation under the legal, relevant provisions, such as the Land Appropriation Act.

5. Establishment of the Industrial Estate and Performing Business Operation in the Industrial Estate by the Investors (Industrial Estate Authority of Thailand Act, B.E. 2522 (A.D. 1979)

Establishment of the industrial estate is a cooperative, land-appropriation scheme for industrial purposes, between the investor who has founded the industrial estate and the IEAT, a state agency, under the Industrial Estate Act.

For operating an industrial business inside an area of the industrial estate, the investors shall implement such under the Industrial Estate Act. For the business operation within the industrial estate, the investors or operators shall receive more privileges and convenience from the state agency concerned than for a business operation outside the industrial estate, i.e. permission to make use of the land; permission to construct the building; permission to operate the plant business; and being permitted to file an application for permission or compliance with the environmental law. In such regard, the IEAT will be the sole agency empowered to consider the application for permission, conduct examination and grant permission under the provisions of related laws in each case; for facilitating the investors in a manner of one-stop service. The government has a policy to have the operators operate their businesses in the same area of the industrial estate; under an order for administering the use of resources by the state and regulating the local environment for the benefit of the general public. This makes management of such public order far easier than simply leaving the operators to engage in their business in random areas throughout the nation.

\section{Construction of Structures in the Security and Safety Zone of the Country}

For the operation of a business relating to the construction of structures in the security and safety zone of the country, such as construction of buildings or structures in the immediate area with air navigation of a commercial airport or the Royal Thai Air Force; the application for construction of the structures must receive permission from the Department of Civil Aviation or the Royal Thai Air Force before proceeding with such construction. The height of the buildings will be considered in applying for permission to construct the buildings with other government agencies under 
the building control law and the Department of Civil Aviation, or the Royal Thai Air Force. Whether to authorise construction or not depends on the consideration made; and a grant of permission to construct shall be made under the reference criteria of ICAO-Annex14, a building standard set by the International Civil Aviation Organisation.

In light of the above, if any foreign investor, i.e. Toyota or McDonalds, wants to set up base in Thailand, then what kind or type of land tenure is allowed? As a foreign entity, can they buy land or buildings for commerce activities outright or can they lease; or do they have to incorporate a local registered company before they can acquire land and buildings? Do they have to have local partners?

\section{Choice of Business Organisation}

In order to set up base in Thailand in terms of tenure under the above stated Clause 1.2 or 1.3, regarding the purchase or ownership of land and real estate, a foreign investor may take into consideration the forming of a limited company to carry out such business. The applicable law in this regard is provisions of the $\mathrm{CCC}$ relating to limited companies.

In general, any foreign investor who wishes to invest in any Thai company is allowed to subscribe shares at the ratio of not more than $50 \%$ of the total registered capital (i.e. no foreigner can hold shares in a Thai company at the ratio of more than $49 \%$ of the registered capital); or may seek permission to be the land owner in the case of the foreign investor enjoying the BOI right; apply for permission to be the land owner for performing the industrial business in the industrial estate zone; or is granted with the concession for the petroleum drilling.

Alternatively, any foreign investor may choose to do business as permitted under the foreign business law, i.e. the Foreign Business Act, B.E. 2542 (A.D. 1999).

\section{NEW DRAFT LAW RELATING to LAND AND BUILDING TAXES EXPECTED}

TO BE IN ForCE BY B.E. 2560 (A.D. 2017) (SUPERSEDING THE CURRENT

Thai Property Tax LaW, Namely the LaW on Building and Land TAXES, AND LOCAL ADMINISTRATION TAXES)

Levying of the present property tax in Thailand has been from the holding of real estate, relating to the type of buildings, structures and land connecting the buildings and structure, since 1932 until now. The tax base prescribed is the rentable price, which provides discretion to the competent state official to assess or fix the tax base value. Exercise of the competent 
official's discretion may give rise to unfairness or impartiality, and such discretion has no standard for controlling the fixing of the tax base value. The competent official exerts discretion in unequally fixing the price or value in levying the land tax to the land owner. Moreover, there are various plots of wasteland in Thailand possessed or owned by major investors or capital groups, thus causing a disadvantage to the underprivileged people and not conforming to the governmental policy on such issue; which has an objective of making the underprivileged or low-income people become land owners and making use of the land in order to make a living. At present, a low rate of taxes has been levied for said wasteland, and a substantial number of them are held or owned by the major capital groups of Thailand. The current government thus has a policy to alter an approach and impose a new rule for levying the land tax for the land so that it is at the highest sustainable level and best used.

The main essence of the new draft law anticipated to be in force is for collecting the property tax from the land with structures, as well as wasteland, in order to resolve the current tax-collection issue. The government thus imposes application of the tax imputation basis or base in accordance with the appraised land and structure value; by authorising the Treasury Department as the sole agency to determine and consider the appraised land and structure value throughout the nation, as well as adjust the appraised value every four years and impose the tax rate for the wasteland by calculating it in such a way as to increase the tax rate every year.

\section{SECURITISATION OF THE COMPANY's Assets, Which ARE THE REAL \\ Estate OR Right IN THE REAL Estate, to Be SECURITIES UNDER THE CATEGORY OF "INSTRUMENT FOR Distribution to THE GENERAL PUBLIC" THROUGH THE ESTABLISHMENT OF THE REIT}

In the past, Thailand has given a right to securitisation from the right in the real estate into fixed-income-type instruments, earned from bringing the exploitation of real estate, in the form of a rent, as the underlying asset through a property fund public offering. However, at present, a right to establish the property fund public offering (mutual fund) with a status of a juristic person has been cancelled, and a right to establish the REIT (the property fund) without the status of a juristic person under the law has been granted instead; having a custodian as a holder of the right in the real estate, and a REIT Manager performing administration of the property in bringing the right to the real estate for exploitation for the benefit of the 
investors/Trust Certificate Holders, which is the same principle as the Collective Investment Scheme of REIT employed by many nations currently.

The foreign investors have enjoyed the same investment privileges with regard to taxation as Thai nationals, i.e. they can own the real estate as a settlor (in law, a settlor is a person who settles property on trust law for the benefit of beneficiaries. In some legal systems, a settlor is also referred to as a trustor or, occasionally, a grantor or donor) and Trust Certificate Holders. The Trust Certificate Holders are not shareholders of the company; they are merely the Trust Certificate Holders in the trust. The foreigners are entitled to hold the "trust units" in the same way as Thai people. The trust units are not shares of the company. There is no restriction on the number of investment units in investment by holding the trust units; which differs from investment by holding shares in the company limited to not exceeding 49 percent of the registered capital. The investors gain a tax benefit exceeding investment in the company's shares. A net profit from exploitation of the right in the real estate by REIT is tax-exempted under Thai law, and a share of profits from REIT, paid to the Trust Certificate Holders, shall be taxed (a withholding tax) at the rate of $10 \%$ of the profit sharing amounts. With respect to the investment in the equity instrument, after the company pays the corporate income tax at the rate of $20 \%$ of the net profit; if the company pays dividends to shareholders, the dividends paid to the shareholders shall be subject to a withholding tax at the rate of $10 \%$ of the received dividends.

At present, there is the ASEAN CIS Framework between Thailand, Malaysia and Singapore. Its aim is to provide a privilege on the legal limits to an inter-party offer to sell the investment units among the member countries. The said agreement shall trigger an expansion and also increase the development of future investment in the real estate business in Thailand.

\section{CONCLUSION}

At the current very competitive economical and business environment Thailand very much welcomes foreign investment into the country, but sets various safeguards to ensure there is adequate laws in place to meet the objectives of the investors and to assist investors to get a good return of their investment. Compared to other countries within this region, Thailand is doing a lot to improve its infrastructure and logistics to improve the movement of goods and passengers, hence, foreign investment is essential. To encourage further investment, Thailand enacts and improve laws to create a safe ground for investment and to encourages the growth and to boost the economy. Thailand is rich in resources, i.e., labour, land, technical 
expertise, food, etc., and the government intents these resources are being utilized in the right way while harmonizing with its intention in line with ASEAN Economic Community, which now plays a big role in development in the Asean region. Existing laws are being always modified to ensure it is in line with the Government's intention while ensuring this welcomes foreign direct investment into the country. 